\title{
Measuring the Conformational Stability of a Protein by Hydrogen Exchange
}

\section{Beatrice M. P. Huyghues-Despointes, C. Nick Pace, S. Walter Englander, and J. Martin Scholtz}

\section{Introduction}

Measuring the conformational stability of a protein is one key to solving the protein folding problem. It is also of practical importance for answering questions such as these:

1. How stable is a protein under physiological conditions?

2. How does the stability depend on temperature, $\mathrm{pH}$, and salt concentration?

3. Can the stability be increased by osmolytes?

4. Can the stability be increased by ligands that bind the native state?

5. Does an amino-acid substitution increase or decrease the stability?

Thus, reliable techniques for measuring the conformational stability of proteins are essential. In this chapter, we briefly review the traditional methods that have been used to measure the conformational stability of a protein, and describe in more detail how the conformational stability can be measured using hydrogen-exchange rates as monitored by nuclear magnetic resonance (NMR). 


\section{Determining Protein Conformational Stability}

The conformational stability is defined as the free-energy change of the unfolding reaction, $\mathrm{F} \Leftrightarrow \mathrm{U}$, under ambient conditions (generally around room temperature and neutral $\mathrm{pH}$ ): $\Delta \mathrm{G}_{\mathrm{U}}=\mathrm{G}_{\mathrm{U}}-\mathrm{G}_{\mathrm{F}}$. It can be evaluated using the relationship $\Delta \mathrm{G}_{\mathrm{U}}=-\mathrm{RT} \ln \mathrm{K}_{\mathrm{U}}$, where $\mathrm{K}_{\mathrm{U}}$ is the equilibrium constant of the unfolding reaction. Measuring the conformational stability and changes in stability of proteins that differ slightly in structure helps to define the forces that determine the conformations of proteins and optimize their stabilities. The stability of the folded conformation is a delicate balance between compensating forces: favorable hydrophobic, van der Waals, and hydrogen-bonding interactions and unfavorable conformational entropy. The result is that the folded protein is only marginally stable, generally $5-15 \mathrm{kcal} / \mathrm{mol}$ under native conditions (1).

A protein exists predominantly in the folded conformation under ambient conditions, but rarely, as dictated by the Boltzmann relationship, $\mathrm{P}_{\mathrm{f}} / \mathrm{F}=\mathrm{e}^{-\Delta \mathrm{G}_{U} / \mathrm{RT}}$, this conformation will unfold to partially unfolded or completely unfolded higher energy conformations (see Fig. 1). As a result, it is difficult to detect the unfolded conformations and to directly measure $\mathrm{K}_{\mathrm{U}}$ under native conditions. In the traditional methods, the conformational stability is extrapolated from stabilities obtained under denatured conditions, while in the hydrogen-exchange experiments, conformational stability is determined directly under native conditions.

\subsection{Traditional Methods: Solvent and Thermal Denaturation}

The most common way to estimate the conformational stability of a protein is to tilt the equilibrium to conditions where the folded and unfolded states are almost equally populated, measure the stability, and extrapolate to obtain the stability under native conditions. Traditional methods of measuring $\Delta \mathrm{G}_{\mathrm{U}}$ are solvent (urea or guanidinium chloride [GdmCl] or thermal denaturation (see Fig. 2) (2). Solvent denaturation curves are generally analyzed using the linear extrapolation method (LEM): 
Relative Population

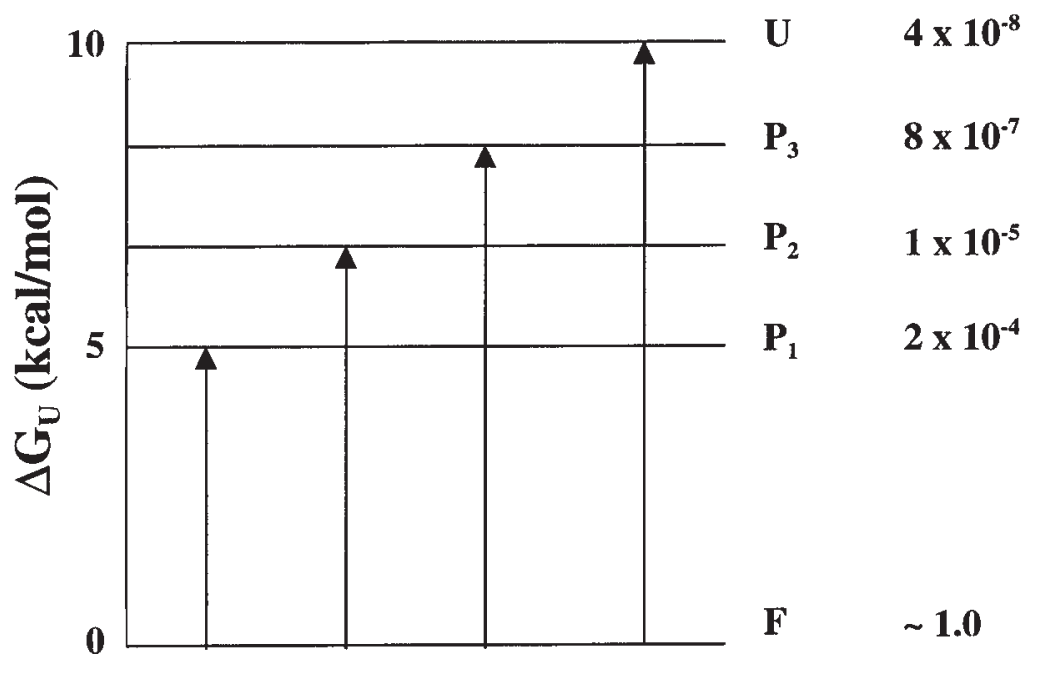

Fig. 1. An energy manifold of states at $25^{\circ} \mathrm{C}$ for a protein having $\Delta \mathrm{G}_{\mathrm{U}}=10 \mathrm{kcal} / \mathrm{mol}$, including the folded (F) and unfolded (U), and partially unfolded states $\left(\mathrm{P}_{\mathrm{i}}\right)$.

$$
\Delta \mathrm{G}=\Delta \mathrm{G}_{\mathrm{U}}\left(\mathrm{H}_{2} \mathrm{O}\right)-m[\text { denaturant }]
$$

where $m$ is a measure of the dependence of $\Delta \mathrm{G}$ on denaturant, and $\Delta \mathrm{G}_{\mathrm{U}}\left(\mathrm{H}_{2} \mathrm{O}\right)$ is an estimate of the conformational stability that assumes that the linear dependence of $\Delta \mathrm{G}$ on denaturant observed in the transition region continues to $0 \mathrm{M}$ denaturant. Thermal denaturation experiments yield the melting temperature, $\mathrm{T}_{\mathrm{m}}$, the enthalpy change at $\mathrm{T}_{\mathrm{m}}, \Delta \mathrm{H}_{\mathrm{m}}$, and the heat-capacity change, $\Delta \mathrm{C}_{\mathrm{p}}$, which can then be used to calculate $\Delta \mathrm{G}_{\mathrm{U}}$ at any temperature $\mathrm{T}, \Delta \mathrm{G}_{\mathrm{U}}(\mathrm{T})$, with the Gibbs-Helmholtz equation:

$$
\Delta \mathrm{G}_{\mathrm{U}}(\mathrm{T})=\Delta \mathrm{H}_{\mathrm{m}}\left(1-\mathrm{T} / \mathrm{T}_{\mathrm{m}}\right)+\Delta \mathrm{C}_{\mathrm{p}}\left[\mathrm{T}-\mathrm{T}_{\mathrm{m}}-\mathrm{T} \ln \left(\mathrm{T} / \mathrm{T}_{\mathrm{m}}\right)\right]
$$

The equilibrium between the folded and unfolded states can be monitored by calorimetry (3), or by using spectroscopic techniques such as UV absorbance spectroscopy, fluorescence, and circular dichroism that monitor the changes in conformational states of a protein (4). 


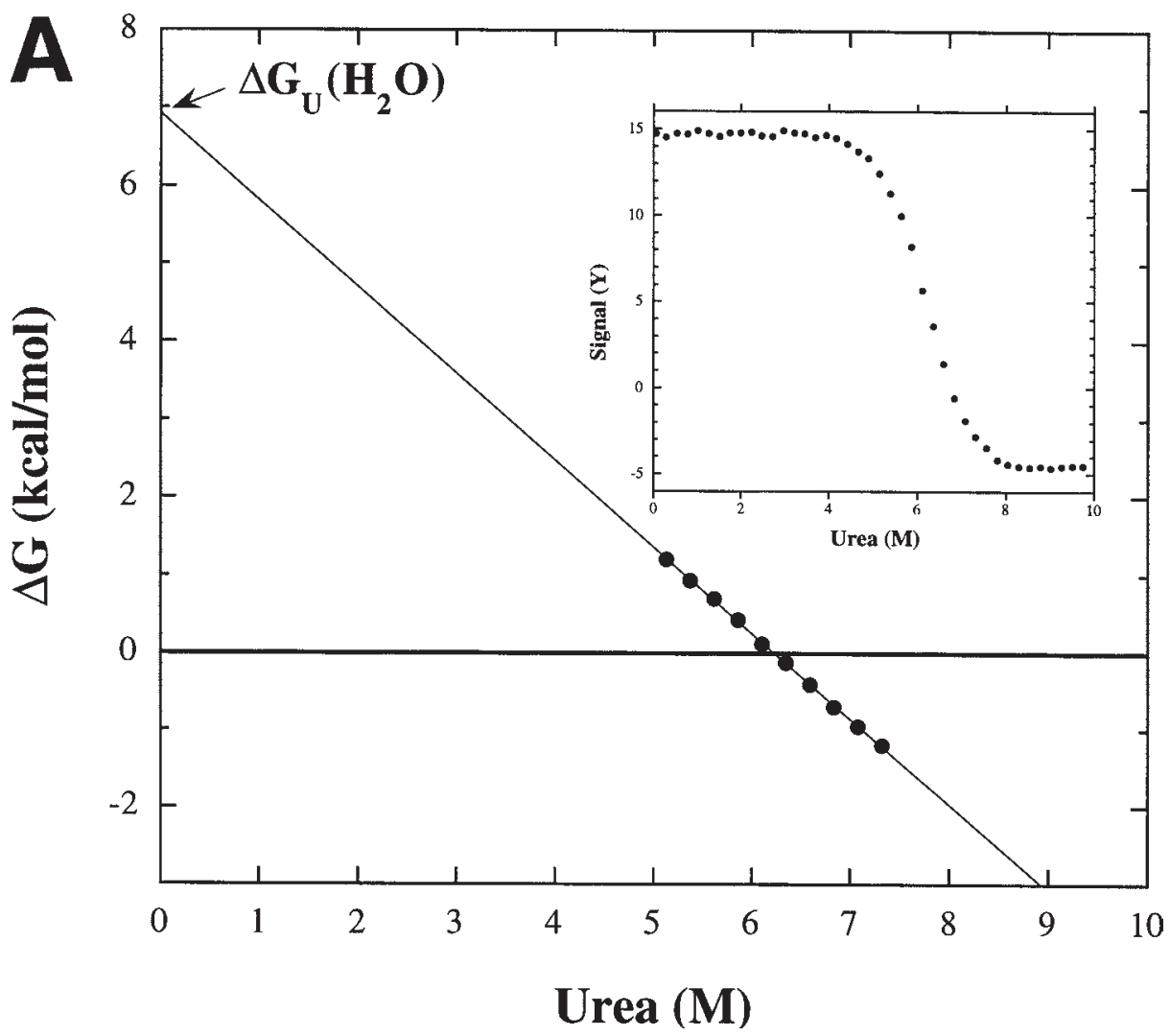

Fig. 2. (A) The inset shows a typical urea unfolding curve for a small monomeric protein. The data in the transition region can be extrapolated to determine $\Delta \mathrm{G}_{\mathrm{U}}\left(\mathrm{H}_{2} \mathrm{O}\right)$ using the LEM (Eq. 1).

There are several problems with these techniques. Traditional methods are usually unable to detect unfolded forms under ambient conditions because their concentrations are far too low. These methods for determining the conformational stability also depend on some basic limiting assumptions. First, they require that the folding transition of a protein be fully reversible, with a known and finite number of observable states. Above, we show the simplest examplea two-state mechanism - but the models can be expanded for analysis of multimeric protein systems or proteins that fold by mechanisms with intermediate states (5). 


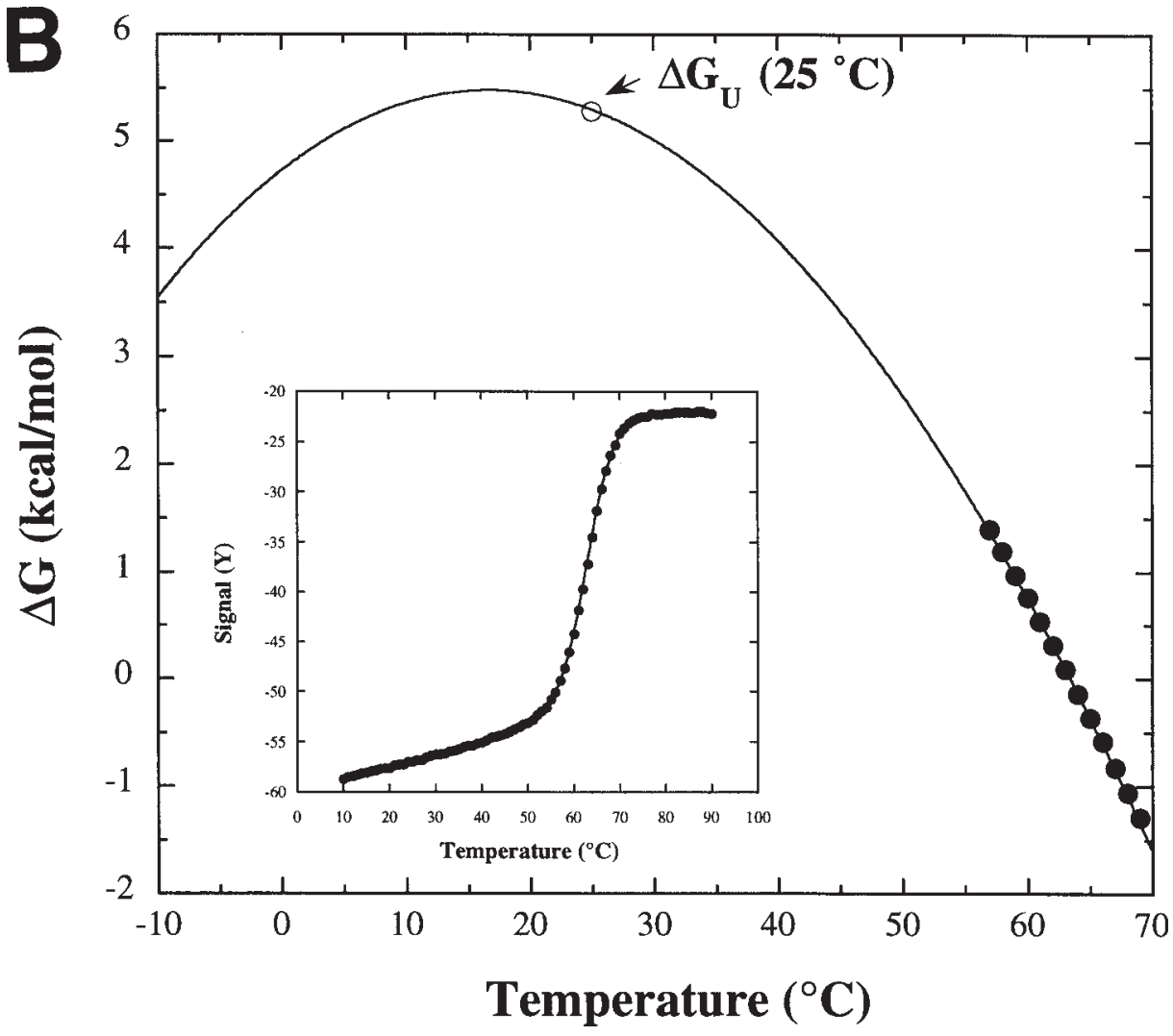

Fig. 2. (continued) (B) The inset shows a typical thermal unfolding curve for a small mononmeric protein. The data in the transition region of a thermal unfolding curve can be extrapolated to obtain $\Delta \mathrm{G}_{\mathrm{U}}$ at a desired reference temperature such as $25^{\circ} \mathrm{C}$ using the Gibbs-Helmholtz relationship (Eq. 2).

Second, both methods require a long extrapolation from unfolding to ambient conditions. The LEM assumes that the dependence on denaturant can be extended linearly to the absence of denaturant. This may not always occur, especially for $\mathrm{GdmCl}$, a salt that can alter the stability of a protein at low denaturant concentrations through an ionic strength effect (see ref. 6 and references therein). For thermal denaturation, the extrapolation from higher temperatures to ambient temperatures requires an accurate value of $\Delta \mathrm{C}_{\mathrm{p}}$. At best, $\Delta \mathrm{C}_{\mathrm{p}}$ can be measured to approx $\pm 10 \%$ with calorimetry. 
Finally, the unfolded states in denaturant or at high temperatures may not be thermodynamically equivalent to the unfolded states under ambient conditions.

\subsection{The New Method: Hydrogen Exchange}

When a protein is placed in $\mathrm{D}_{2} \mathrm{O}$, amide hydrogens in the protein begin to exchange with deuterium. The rate of exchange of an amide depends on its environment in the protein. An unprotected amide exchanges readily with the solvent. In contrast, an amide that is shielded from solvent by burial and/or hydrogen bonding can exchange only a small fraction of time when it unfolds to a higher energy conformation that is exposed to solvent. The exchange of a backbone amide proton can occur by local fluctuations, such as the breaking of only a few hydrogen bonds, or by a larger global unfolding event. The result is that exchange rates of amide protons in a protein vary widely, providing a clear view of the higher energy unfolded states under native conditions (see Fig. 1) (7).

We describe here a NMR technique that identifies amides that exchange from the globally unfolded protein. Hydrogen-exchange measurements under fully native conditions can provide a direct estimate of the conformational stability of a protein without having to drive the protein through its macroscopic unfolding transition. This technique, which can measure the conformational stability of a protein, may not be possible by traditional methods because folding is irreversible or does not approach a two-or three-state folding mechanism.

\section{The Hydrogen-Exchange Process}

\subsection{The Rate Constants Governing Exchange}

The exchange process can be described using a general two-step model:

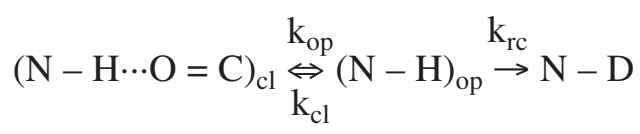


where $\mathrm{k}_{\mathrm{op}}$ and $\mathrm{k}_{\mathrm{cl}}$ are the rate constants for structural opening and closing, respectively, and $(\mathrm{N}-\mathrm{H})_{\mathrm{op}}$ is the open form that exchanges with solvent at the intrinsic rate constant $\mathrm{k}_{\mathrm{rc}}$, where $\mathrm{rc}$ stands for random coil $(\mathbf{8 , 9 )}$. The second step is written as an irreversible reaction because of exchange with a vast excess of solvent $\mathrm{D}_{2} \mathrm{O}$. The measurable rate constant $\mathrm{k}_{\mathrm{ex}}=\mathrm{k}_{\mathrm{op}} \mathrm{k}_{\mathrm{rc}} /\left(\mathrm{k}_{\mathrm{op}}+\mathrm{k}_{\mathrm{cl}}+\mathrm{k}_{\mathrm{rc}}\right)$. If the protein is present mainly in the open form $\left(\mathrm{k}_{\mathrm{op}}>>\mathrm{k}_{\mathrm{cl}}\right), \mathrm{k}_{\mathrm{ex}}=\mathrm{k}_{\mathrm{rc}}$. If the protein is present mainly in the closed form $\left(\mathrm{k}_{\mathrm{op}}<<\mathrm{k}_{\mathrm{cl}}\right)$, then two mechanisms could potentially occur, depending on conditions, either as two distinct processes or in combination $(\mathbf{1 0}, \mathbf{1 1})$.

The EX1 exchange conditions (monomolecular exchange) exist when $\mathrm{k}_{\mathrm{cl}}<<\mathrm{k}_{\mathrm{rc}}$, so that $\mathrm{k}_{\mathrm{ex}}=\mathrm{k}_{\mathrm{op}}$. The EX2 exchange conditions (bimolecular exchange) exist when $\mathrm{k}_{\mathrm{cl}}>>\mathrm{k}_{\mathrm{rc}}$, so that $\mathrm{k}_{\mathrm{ex}}=\mathrm{K}_{\mathrm{op}} \mathrm{k}_{\mathrm{rc}}$, where $\mathrm{K}_{\mathrm{op}}$ is the equilibrium constant for structural opening $\left(\mathrm{k}_{\mathrm{op}} / \mathrm{k}_{\mathrm{cl}}\right)$. Thus, under EX2 conditions, the free energy of structural opening is given by:

$$
\Delta \mathrm{G}_{\mathrm{HX}}=-\mathrm{RT} \ln \left(\mathrm{k}_{\mathrm{ex}} / \mathrm{k}_{\mathrm{rc}}\right) .
$$

One expects a subset of the $\Delta \mathrm{G}_{\mathrm{HX}}$ values to generally represent the complete unfolding reaction; thus, it has been proposed that the average of the three largest $\Delta \mathrm{G}_{\mathrm{HX}}$ values calculated using Eq. 4 provides a reasonable estimate of the conformational stability of a protein (12).

\subsection{The $k_{r c}$ Values from Model Peptides}

Exchange from the open form depends on $\mathrm{k}_{\mathrm{rc}}$. The $\mathrm{k}_{\mathrm{rc}}$ value can be approximated by the chemical exchange rates of amide groups in nonstructured peptides. The rate constants in short (1-5 amino acids long) peptides and in poly-DL-alanine (PDLA) have been measured $(9,13,14)$. The results show that exchange-rate constants of backbone amide protons are dependent on $\mathrm{pH}$, temperature, identity of neighboring side-chain residues in the sequence, solvent isotope effects, and small ionic strength effects. The exchange-rate constants for alanine-based reference peptides at low ionic strengths and $20^{\circ} \mathrm{C}$ are shown in Table $\mathbf{1 .}$ 


\section{Table 1}

\section{H to D Exchange Rate Constants for Alanine-Based Models at $293 \mathrm{~K}^{a}$}

\begin{tabular}{lccr}
\hline Model & $\begin{array}{c}\log \mathrm{k}_{\mathrm{A}} \\
\left(\mathrm{M}^{-1} \mathrm{~min}^{-1}\right)\end{array}$ & $\begin{array}{c}\log \mathrm{k}_{\mathrm{B}} \\
\left(\mathrm{M}^{-1} \min ^{-1}\right)\end{array}$ & $\begin{array}{r}\log \mathrm{k}_{\mathrm{W}} \\
\left(\mathrm{min}^{-1}\right)\end{array}$ \\
\hline $\mathrm{N}^{-A c-A}-\underline{\mathrm{A}}-\mathrm{A}-\mathrm{N}^{\prime} \mathrm{MA}^{b}$ & 2.04 & 10.36 & -1.5 \\
PDLA $^{c}$ & 1.62 & 10.05 & -1.5 \\
\hline
\end{tabular}

${ }^{a}$ These values are specific for $\mathrm{NH}$ to $\mathrm{ND}$ exchange under normal low salt conditions, using $\mathrm{pD}=\mathrm{pH}^{*}+0.4$ and $\mathrm{pK}_{\mathrm{a}}=15.05$ for the $\mathrm{D}_{2} \mathrm{O}$ at $20^{\circ} \mathrm{C}$. These data are from Table 3 in Bai et al. (9).

$b_{\mathrm{L}}$-alanine tripeptide blocked by $\mathrm{N}$-acetyl at $\mathrm{N}$-terminus and $\mathrm{N}^{\prime}$-methylamide at C-terminus.

${ }^{c}$ poly-DL-alanine.

The NH to ND chemical exchange process can be acid $\left(\mathrm{k}_{\mathrm{H}}\right)$, base $\left(\mathrm{k}_{\mathrm{OH}}\right)$, or water catalyzed $\left(\mathrm{k}_{\mathrm{W}}\right)$, yet the latter generally makes only a negligible contribution:

$$
\mathrm{K}_{\mathrm{rc}}=\mathrm{k}_{\mathrm{A}} 10^{-\mathrm{pD}}+\mathrm{k}_{\mathrm{B}} 10^{\left[\mathrm{pD}-\mathrm{pK}_{\mathrm{D}}\right]}+\mathrm{k}_{\mathrm{W}}
$$

where $\mathrm{pD}$ is the corrected reading in $\mathrm{D}_{2} \mathrm{O}$ (see below) and $\mathrm{pK}_{\mathrm{D}}$ is the molar ionization constant of $\mathrm{D}_{2} \mathrm{O}$. The rate of exchange of a backbone amide reaches a minimum near $\mathrm{pH} \sim 3$ and increases substantially at both $\mathrm{pH}$ extremes, by a factor of 10 per pD unit (Eq. 5). The chemical exchange rate of amide proton of residue $i$ in a sequence is affected by its own side chain and the side chain of residue i-1. For example, we show in Fig. 3 for two dipeptide sequences in RNase $\mathrm{T} 1$ that $\mathrm{k}_{\mathrm{rc}}$ can vary by 20-fold. Fig. 3 also illustrates the dependence of $\mathrm{k}_{\mathrm{rc}}$ on $\mathrm{pH}$.

The intrinsic rate of exchange can also change with temperature. The rate constant for the acid-catalyzed exchange can be modified by:

$$
\mathrm{k}_{\mathrm{A}}(\mathrm{T})=\mathrm{k}_{\mathrm{A}}(293 \mathrm{~K}) \mathrm{e}^{(-\mathrm{Ea}[1 / \mathrm{T}-1 / 293] / \mathrm{R})}
$$

where the activation energy, $\operatorname{Ea}\left(\mathrm{k}_{\mathrm{H}}\right)=14 \mathrm{kcal} / \mathrm{mol}$. Analogous expressions can be made for the base- and water-catalyzed exchange in Eq. 5, where $\mathrm{Ea}\left(\mathrm{k}_{\mathrm{OH}}\right)=17 \mathrm{kcal} / \mathrm{mol}$, and $\mathrm{Ea}\left(\mathrm{k}_{\mathrm{W}}\right)=19 \mathrm{kcal} / \mathrm{mol}$, 


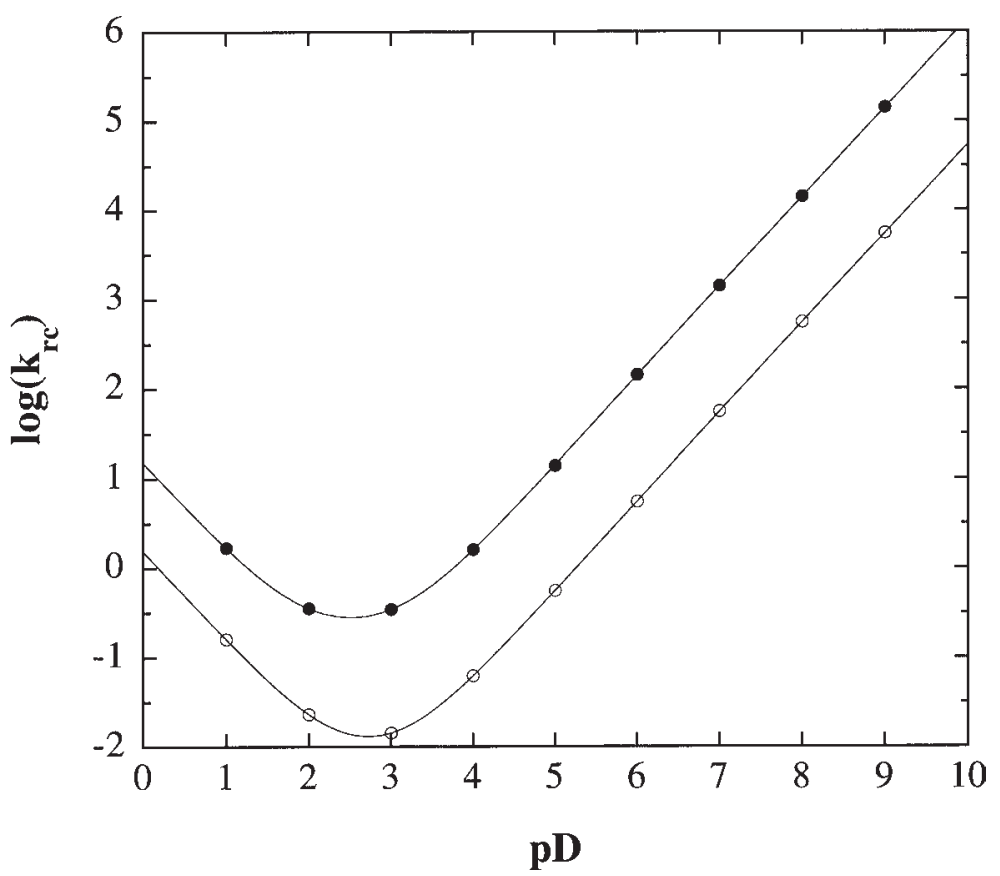

Fig. 3. $\log \left(\mathrm{k}_{\mathrm{rc}}\right)$ vs $\mathrm{pD}$ for two dipeptide sequences, -Gly71-Ser72(๑) and -Val89-Ile90- (O), in RNase T1 using $\mathrm{k}_{\mathrm{rc}}$ values from Bai et al. (9). Curves represent the data fit to Eq. 5.

respectively. To determine $\Delta \mathrm{G}_{\mathrm{HX}}$ in a protein, the exchange-rate constants of random coil peptides can be used to predict $\mathrm{k}_{\mathrm{rc}}$ values for every residue at a particular $\mathrm{pH}$ and temperature. (See the spreadsheet at ftp://hxiris.med.upenn.edu/HX/ to do it for your favorite protein).

\subsection{EX1 and EX2 Conditions}

The exchange process for a globally exchanging residue must be EX2 in order to determine the conformational stability of the protein by the hydrogen-exchange method. Three methods are used to establish whether an amide proton exchanges by an EX1 or EX2 mechanism (15). The simplest method is to plot $\log \mathrm{k}_{\mathrm{ex}}$ for several 
amide protons at two different $\mathrm{pH}$ values above $\mathrm{pH} 4.0$ and in a $\mathrm{pH}$ region where the stability of the protein changes as little as possible. For the EX2 process, the hydrogen-exchange rates for each $\mathrm{NH}$ group should change by 10 -fold, with a one-unit change in $\mathrm{pH}$, showing the expected $\mathrm{pH}$ dependence on $\mathrm{k}_{\mathrm{rc}}$ (see Fig. 3). In the EX1 process, $\mathrm{k}_{\mathrm{ex}}$ depends only on $\mathrm{k}_{\mathrm{op}}$, which is likely to be less dependent on $\mathrm{pH}$. As a result, we would observe little to no rate variation with $\mathrm{pH}$ in the EX1 regime.

Another test of EX2 vs EX1 kinetics uses the nuclear Overhauser effect (NOE) (15-18). We can measure a decrease in the NOE intensity between two adjoining residues as hydrogen-exchange progresses. In the EX1 limit, two amide protons will exchange at the same rate, so that the decay rate of the NOE will be equal to the exchange rate of a single amide proton. Conversely, in the EX2 limit, two amide protons will exchange independently and often with different chemical exchange rates. Therefore, the decay rate of the NOE will be the sum of the exchange rates of the two adjoining amide protons. This method is often arduous, and errors in measurement can be significant (15).

A third method is simply to compare the $\Delta \mathrm{G}_{\mathrm{HX}}$ values for neighboring amide groups with their corresponding $\mathrm{k}_{\mathrm{rc}}$ values. In an EX2 process, the same $\Delta \mathrm{G}_{\mathrm{HX}}$ values are likely to have widely different $\mathrm{k}_{\mathrm{rc}}$ values. The opposite holds true for the EX1 process.

\section{4. $\Delta G_{H X}$ for Measurable Amide Protons}

The hydrogen-exchange technique provides a glimpse into the distribution of unfolded conformations at native conditions. Exchange of an amide proton with solvent deuterium occurs only through exchange-competent, higher-energy forms. The amide groups that are most protected from exchange have the largest stabilities and may be limited to exchange only from the fully unfolded state ("global"). Residues with intermediate and low stabilities (or protection) exchange by either fluctuations in the native state ("local") or by partial unfolding ("subglobal"). Here, we describe an NMR technique that identifies only the global-exchanging resi- 
dues. Monitoring hydrogen exchange in response to external perturbants, such as temperature, solvent denaturants (19-25) or pressure (26), can help to decipher the exchange processes of local and subglobal amide groups.

Hydrogen-exchange studies with mutant proteins have also been performed where the change in stability upon mutation, $\Delta \Delta \mathrm{G}_{\mathrm{HX}}$, can be obtained by:

$$
\Delta \Delta \mathrm{G}_{\mathrm{HX}}=\left(\Delta \mathrm{G}_{\mathrm{HX}}\right)_{\mathrm{WT}}-\left(\Delta \mathrm{G}_{\mathrm{HX}}\right)_{\text {mutant }}=-\mathrm{RT} \ln \left(\mathrm{k}_{\mathrm{ex}}\right)_{\mathrm{WT}} /\left(\mathrm{k}_{\mathrm{ex}}\right)_{\mathrm{mutant}}
$$

The $\mathrm{k}_{\mathrm{rc}}$ values for all residues cancel in Eq. 7, except for the mutation site and the residue $\mathrm{C}$-terminal to the site of the mutation. The residues that exchange by global unfolding will have $\Delta \Delta \mathrm{G}_{\mathrm{HX}}$ values similar to the values determined by the traditional methods. Unfortunately, there can also be nonglobal residues that have $\Delta \Delta \mathrm{G}_{\mathrm{HX}}$ values equal to or even greater than $\Delta \Delta \mathrm{G}_{\mathrm{U}}$ (27). Additional experiments that monitor the effect of an external perturbant on the hydrogenexchange stabilities are required to decipher the stability patterns of nonglobal residues. As a result, hydrogen-exchange studies with mutant proteins cannot in themselves determine the residues that unfold globally.

\section{The NMR Experiment}

\subsection{Establishing Experimental Conditions}

The hydrogen-exchange experiment by NMR entails monitoring the decay of individual proton resonances over time as they exchange with solvent deuterium. We assume that standard sequential NMR assignment techniques have been used to identify amide resonances that persist upon the addition of deuterium. Normally, the overcrowding of proton resonances in a protein limits the usefulness of $1 \mathrm{D}$ proton spectra. Instead, popular two-dimensional experiments have been used, such as proton-detected magnitudemode Correlation Spectroscopy (COSY), and more recently, inverse-detected ${ }^{15} \mathrm{~N}$ Heteronuclear Single Quantum Coherrence (HSQC). For hydrogen exchange, the HSQC experiment provides 
better resolution when observing the exchange of many exchangeable backbone amide groups in larger proteins (15-25 kDa), and in most cases, HSQC spectra can be acquired in less time. The limitations to the heteronuclear approach are that the protein must be uniformly labeled with ${ }^{15} \mathrm{~N}$-usually by overproduction in bacteria, grown in minimal media where yields are generally reduced. ${ }^{15} \mathrm{~N}$-labeled precursors are expensive (although prices are steadily decreasing), and some degree of technical expertise of the NMR hardware and software is required.

A positive attribute of measuring the conformational stability by hydrogen exchange is that only the exchange rates of the most stable $\mathrm{NH}$ groups must be determined. This simplifies assignments and in most cases, simple 1D-proton spectra may be taken to collect the data. The most stable amide resonances are usually the ones that persist over the longest time. Most other resonances disappear from the spectra by the time the most stable amide protons begin to exchange. However, caution must be exercised, because the most stable residue may not always be the slowest exchanging residue. As shown in Fig. 3 and Eq. 4, $\mathrm{k}_{\mathrm{rc}}$ varies with sequence and can affect the exchange time and the stability value of a residue. To be safe, the exchange of at least the 10 slowest exchanging amide protons should be monitored.

It is important to establish the best $\mathrm{pH}$ and temperature conditions to monitor the decay of the most stable NH groups. The random coil rate of each residue and the stability of the protein play important roles in determining the best experimental conditions. For example, RNase $\mathrm{T} 1$ has a bell-shaped stability vs $\mathrm{pH}$ profile with a stability maximum of $\sim 13 \mathrm{kcal} / \mathrm{mol}$ near $\mathrm{pH} 5.0$ and $25^{\circ} \mathrm{C}$ in $\mathrm{D}_{2} \mathrm{O}$ (28). If we monitor exchange at these conditions, the most stable residues would not exchange for over 100 years! As a result, experimental conditions must be chosen to allow the data to be collected in a reasonable amount of time. If we raise the $\mathrm{pH}$ or increase the temperature for RNase $\mathrm{T} 1$, the exchange is considerably faster $(\mathrm{pD}$ $7.7,25^{\circ} \mathrm{C}-3-6$ months, and $40^{\circ} \mathrm{C}$-days). Another method to reduce the time of exchange at a desired experimental condition is 
to perform measurements at two or more concentrations of denaturant where the protein is still fully folded (the pretransition region of Fig. 2A), and extrapolate to the $\Delta \mathrm{G}_{\mathrm{HX}}$ in the absence of denaturant using Eq. 1. With both these techniques, it is important to test whether the exchange process is still in the EX2 regime. Conversely, if a protein is marginally stable, the temperature or the $\mathrm{pH}$ can be decreased in order to observe the decay of the most stable amide protons. Stabilities in a range of $4-10 \mathrm{kcal} / \mathrm{mol}$ can be measured using the hydrogen-exchange technique described here. A good starting point is to perform one-dimensional hydrogen-exchange experiments at several different conditions. If exchange is too slow or too fast, adjust the conditions until the most stable residues exchange in a reasonable amount of time and by the EX2 process.

\subsection{Sample Preparation}

NMR samples are prepared by dissolving the protein in an $\mathrm{H}_{2} \mathrm{O}$ buffered solution. A $0.5-2 \mathrm{~m} M$ solution of protein $(0.5-1.0 \mathrm{~mL})$ is required. The one-dimensional experiment needs less protein than the two-dimensional experiment. The $\mathrm{pH}$ of this solution should be equal to the desired $\mathrm{pD}$ of the deuterated NMR sample. The $\mathrm{pD}$ of a solution in $\mathrm{D}_{2} \mathrm{O}$ is the $\mathrm{pH}$ meter reading $\left(\mathrm{pH}^{*}\right)$ plus $0.4\left(\mathrm{pD}=\mathrm{pH}^{*}+\right.$ 0.4) (29). Measuring the $\mathrm{pH}^{*}$ of a deuterated solution is performed as follows:

1. Use appropriate standard $\mathrm{pH}$ buffers in $\mathrm{H}_{2} \mathrm{O}$ to calibrate your $\mathrm{pH}$ meter, considering the effect of temperature on the buffers.

2. Allow the electrode to soak in $\mathrm{D}_{2} \mathrm{O}$ until the meter reading is steady (5-10 $\mathrm{min})$.

3. Read the $\mathrm{pH}$ meter value of your sample $\left(\mathrm{pH}^{*}\right)$ and make the appropriate correction for $\mathrm{pD}$.

It is important to ensure that the protein sample is fully dissolved and at equilibrium before exchanging the $\mathrm{H}_{2} \mathrm{O}$ for $\mathrm{D}_{2} \mathrm{O}$. If any particulate remains, centrifuge the sample and place the solution in a fresh Eppendorf tube. Buffers that are silent in the NMR experiment 
should be used-such as phosphate that lacks protons or one such as acetate, which can be purchased inexpensively in a deuterated form. The sample can be exchanged into $\mathrm{D}_{2} \mathrm{O}$ by using a spin-column (Isolab, Inc.). The spin-column approach can be performed as follows:

1. Swell $1 \mathrm{~g}$ of $\mathrm{G}-25$ resin in $10 \mathrm{~mL}$ of $\mathrm{D}_{2} \mathrm{O}$ for a minimum of $3 \mathrm{~h}$.

2. Remove fines by stirring and replacing with an equal vol of fresh liquid (2-3 times), pour deuterated buffer onto the resin for the last volume exchange, and equilibrate for $10 \mathrm{~min}$.

3. Pour the resin into the spin column $(\sim 3 \mathrm{~mL})$ and wash the resin several times with $0.5-1.0 \mathrm{~mL}$ volumes of deuterated buffer, by spinning the column in a swinging bucket benchtop centrifuge at $\sim 1000 \mathrm{~g}$ for 1-min intervals. Be sure to balance the rotor by using a dummy column with resin in it.

4. Exchange the protein solution in $\mathrm{H}_{2} \mathrm{O}$ with $\mathrm{D}_{2} \mathrm{O}$ by loading the sample in $\mathrm{H}_{2} \mathrm{O}$ onto the column and spinning the column for a 1-min interval. The number of spins and the vol of sample added can be adjusted so that a final vol of recovered sample is $\sim 0.7 \mathrm{~mL}$ and protein yield is $80-90 \%$. (After the experiment, if the protein is valuable, one can rescue the rest of the protein left on the column by rinsing with several volumes of buffer.)

5. Immediately after exchange, transfer the solution to a NMR tube, and quickly adjust the $\mathrm{pH}^{*}$ of your solution with $\mathrm{NaOD}$ or $\mathrm{DCl}$ if it has changed. The $\mathrm{pH}^{*}$ in the NMR tube can be measured using a long, thin electrode from Ingold.

6. Place the sample in the NMR spectrometer with the probe temperature set at the appropriate temperature, and acquire a data set.

7. Measure the $\mathrm{pH}^{*}$ of the sample after the conclusion of the NMR data set.

\subsection{NMR Data and Analysis}

NMR spectra must be collected over time. The NMR sample should be equilibrated in a water bath at the appropriate temperature if the NMR data are not acquired in a single time period. The spectra are processed by standard processing programs. The peak intensities for each residue can be measured either by peak heights (onedimensional experiments) or by volume integration (two-dimensional 
crosspeaks). These measurements can fit to a single exponential function, $\mathrm{A}=\mathrm{A}_{0}\left[\mathrm{e}^{\left(-\mathrm{ex}^{\mathrm{t}}\right)}\right]+\mathrm{C}$, where $C$ is the baseline noise of a particular spectra caused by residual water in the sample. With partial or completely overlapping peaks, the exchange data may be fit to a sum of exponentials, especially if rates for amide protons differ by more than approximately threefold. The exchange rate should be measured only after the peak is approx 50\% exchanged. The errors in stability are the largest for residues whose hydrogen exchange rates are either very fast or very slow. For a typical exchange experiment, two fold variations in the rate only affect $\Delta \mathrm{G}_{\mathrm{HX}}$ by $0.4 \mathrm{kcal} / \mathrm{mol}$.

\section{Comparison of $\Delta \mathbf{G}_{H X}$ and $\Delta \mathbf{G}_{U}$}

The measured hydrogen-exchange stabilities of the most stable residues are generally higher than the conformational stabilities measured by urea and thermal denaturation, as shown for a variety of proteins in Table 2. There are two main reasons for the discrepancies: solvent isotope effects and proline isomerization effects.

\subsection{Solvent Isotope Effect}

To compare denaturation and hydrogen-exchange experiments, the traditional techniques must be performed in $\mathrm{D}_{2} \mathrm{O}$. At this time, we cannot predict whether a protein will be more or less stable in $\mathrm{D}_{2} \mathrm{O}$ than in $\mathrm{H}_{2} \mathrm{O}$, since many factors affect the solvent isotope effect of a protein (30). We have ample evidence from data by Makhatadze et al. (31), the review by Oas and Toone (30), and HuyghuesDespointes et al. (12) that $\Delta \mathrm{G}_{\mathrm{U}}$ values can differ by $\pm 0-2 \mathrm{kcal} / \mathrm{mol}$ in $\mathrm{H}_{2} \mathrm{O}$ compared to $\mathrm{D}_{2} \mathrm{O}$, and the difference may be dependent on $\mathrm{pH}$.

\subsection{Proline Isomerization Effect}

Denatured states at native-state conditions in the hydrogenexchange experiments differ from denatured states under equilibrium unfolding conditions in traditional experiments. Most peptide bonds in a folded protein are in a trans conformation. Only $0.03 \%$ 
Table 2

Comparison of Conformational Stabilities Measured by Hydrogen Exchange and Traditional Methods ${ }^{a}$

\begin{tabular}{|c|c|c|c|c|c|}
\hline Protein & $\begin{array}{l}\text { No. of } \\
\text { Proline } \\
\text { cis }\end{array}$ & $\begin{array}{c}\text { Residues } \\
\text { trans }\end{array}$ & $\begin{array}{c}\Delta \mathrm{G}_{\mathrm{HX}} \\
(\mathrm{kcal} / \\
\text { mol })\end{array}$ & $\begin{array}{c}\Delta \mathrm{G}_{\mathrm{HX}} * \\
(\mathrm{kcal} / \\
\mathrm{mol})\end{array}$ & $\begin{array}{l}\Delta \mathrm{G}_{\mathrm{U}}\left(\mathrm{D}_{2} \mathrm{O}\right) \\
(\mathrm{kcal} / \mathrm{mol})\end{array}$ \\
\hline \multirow[t]{2}{*}{ RNase T1 } & \multirow[t]{5}{*}{2} & \multirow[t]{5}{*}{2} & \multirow[t]{5}{*}{10.7} & \multirow[t]{2}{*}{8.2} & 7.9 (UDC) \\
\hline & & & & & 8.0 (TDC) \\
\hline $\mathrm{A} 21 \mathrm{G}^{b}$ & & & & 7.2 & 7.1 (UDC) \\
\hline $\mathrm{G} 23 \mathrm{~A}^{b}$ & & & & 7.1 & 7.0 (UDC) \\
\hline $\mathrm{A} 21 \mathrm{G}+\mathrm{G} 23 \mathrm{~A}^{b}$ & & & & 6.3 & 6.0 (UDC) \\
\hline RNase A & 2 & 2 & & & \\
\hline Mayo and Baldwin & & & $(10.2)$ & 7.8 & 7.7 (DSC) \\
\hline Wang et al. & & & 10.3 & 8.0 & 8.1 (DSC) \\
\hline Neira et al. & & & 9.4 & 7.0 & 7.0 (DSC) \\
\hline barnase & 0 & 3 & 8.3 & 8.1 & 8.3 (DSC) \\
\hline $\mathrm{CI} 2$ & 0 & 5 & 7.6 & 7.1 & $7.0(\mathrm{GDC})$ \\
\hline 434 cro & 0 & 2 & 4.0 & 3.9 & 3.7 (UDC) \\
\hline \multirow[t]{2}{*}{ apocytochrome $b_{562}$} & \multirow[t]{2}{*}{0} & \multirow[t]{2}{*}{4} & \multirow[t]{2}{*}{5.5} & \multirow[t]{2}{*}{5.3} & $5.0(\mathrm{DSC})$ \\
\hline & & & & & $3.3(\mathrm{GDC})$ \\
\hline cytochrome c (equine) & 0 & 4 & & & \\
\hline Bai et al. & & & $(9.3)$ & 9.0 & 9.1 (DSC) \\
\hline Foord and Leatherbarrow & & & 6.4 & 6.1 & $6.1(\mathrm{DSC})$ \\
\hline cytochrome c (yeast) & 0 & 4 & 6.8 & 6.5 & 6.4 (TDC) \\
\hline HEWL & 0 & 2 & 12.4 & 12.2 & 11.7 (DSC) \\
\hline NTL9 & 0 & 1 & 4.8 & 4.7 & $4.7(\mathrm{TDC}+\mathrm{UDC})$ \\
\hline OMTKY3 & 1 & 2 & 8.2 & 7.2 & 7.2 (DSC) \\
\hline \multirow[t]{2}{*}{ PPL } & \multirow[t]{2}{*}{0} & \multirow[t]{2}{*}{0} & \multirow[t]{2}{*}{$(6.9)$} & \multirow[t]{2}{*}{6.9} & 6.7 (TDC) \\
\hline & & & & & $4.9(\mathrm{GDC})$ \\
\hline HPr (Escherichia coli) & 0 & 2 & 5.8 & 5.7 & 4.7 (UDC) \\
\hline \multirow[t]{2}{*}{ src SH3 domain } & \multirow[t]{2}{*}{0} & \multirow[t]{2}{*}{2} & \multirow[t]{2}{*}{6.2} & \multirow[t]{2}{*}{6.1} & 4.7 (TDC) \\
\hline & & & & & 4.7 (GDC) \\
\hline Barstar & 0 & 2 & 6.2 & 6.0 & $5.0(\mathrm{GDC})$ \\
\hline RNase H* (Escherichia coli & li) 1 & 4 & $(10.9)$ & 9.3 & $9.9(\mathrm{GDC})$ \\
\hline RNase H (T. thermophilus) & ) 1 & 11 & $(15.8)$ & 13.8 & 13.3 (GDC) \\
\hline CTXIII $^{c}$ & & 5 & 6.6 & 6.3 & $6.0(\mathrm{GDC})$ \\
\hline RNase $\mathrm{A}^{d}$ & 2 & 2 & 11.8 & 9.6 & $9.2(\mathrm{DSC})$ \\
\hline RNase $\mathrm{Sa}^{e}$ & 1 & 5 & 8.9 & 7.3 & $7.5(\mathrm{GDC})$ \\
\hline T4 lysozyme ${ }^{f}$ & & 3 & $(17.7)$ & 17.5 & $16.0(\mathrm{GDC})$ \\
\hline SNase $^{g}$ & 2 & 4 & & & \\
\hline Unligated & & & 6.4 & 4.4 & 6.1 (UDC) \\
\hline Ligated $\left(\mathrm{Ca}^{2+}\right.$ and pdTp) & & & 8.2 & 6.2 & 7.4 (UDC) \\
\hline SNase $^{h}$ (Unligated) & 2 & 4 & $\sim 6.4$ & $\sim 4.5$ & $4.0(\mathrm{GDC})$ \\
\hline E75A & & & $\sim 4.4$ & $\sim 2.5$ & $2.0(\mathrm{GDC})$ \\
\hline
\end{tabular}




\section{Table 2 (continued)}

\begin{tabular}{|c|c|c|c|c|c|}
\hline Protein & $\begin{array}{c}\text { No. of } \\
\text { Proline } \\
\text { cis }\end{array}$ & $\begin{array}{c}\text { Residues } \\
\text { trans }\end{array}$ & $\begin{array}{c}\Delta \mathrm{G}_{\mathrm{HX}} \\
(\mathrm{kcal} / \\
\mathrm{mol})\end{array}$ & $\begin{array}{c}\Delta \mathrm{G}_{\mathrm{HX}} * \\
(\mathrm{kcal} / \\
\mathrm{mol})\end{array}$ & $\begin{array}{l}\Delta \mathrm{G}_{\mathrm{U}}\left(\mathrm{D}_{2} \mathrm{O}\right) \\
(\mathrm{kcal} / \mathrm{mol})\end{array}$ \\
\hline M26G & & & $\sim 4.4$ & $\sim 2.5$ & $2.3(\mathrm{GDC})$ \\
\hline D77A & & & $\sim 4.1$ & $\sim 2.2$ & 3.1 (GDC) \\
\hline V23A & & & $\sim 3.4$ & $\sim 1.5$ & $2.2(\mathrm{GDC})$ \\
\hline
\end{tabular}

${ }^{a}$ Unless otherwise indicated below, the specific conditions for each protein are given in the footnote to Table 1 in Huyghues-Despointes et al. (12). $\Delta \mathrm{G}_{\mathrm{HX}}$ is the average $\Delta \mathrm{G}_{\mathrm{HX}}$ value of the three most stable residues. $\Delta \mathrm{G}_{\mathrm{HX}}$ values in parentheses were estimated by extrapolation of hydrogen exchange stabilities at higher denaturant concentrations (15). $\Delta \mathrm{G}_{\mathrm{HX}}{ }^{*}=\Delta \mathrm{G}_{\mathrm{HX}}-\Sigma \Delta \mathrm{G}_{\mathrm{pro}} \cdot \Delta \mathrm{G}_{\mathrm{U}}\left(\mathrm{D}_{2} \mathrm{O}\right)$ is measured by the LEM (Eq. 1) using urea (UDC) or GdmCl (GDC) denaturation curves, or by the Gibbs-Helmholtz equation (Eq. 2) using thermal denaturation curves (TDC) or differential scanning calorimetry (DSC).

${ }^{b} \mathrm{pD}=7.4$ and $25^{\circ} \mathrm{C}(27)$.

${ }^{c}$ Cardiotoxin analog III. $\mathrm{pD}=3.6$ and $25^{\circ} \mathrm{C}(39)$.

$d_{\mathrm{pD}}=6.4$ and $25^{\circ} \mathrm{C}$ (40).

${ }^{e} \mathrm{pD}=5.9$ and $30^{\circ} \mathrm{C}$ (D. Laurents, J.M. Pérez-Cañadillas, J. Santoro, M. Rico, D. Schell, C. N. Pace, and M. Bruix, personal communication).

$f_{\mathrm{pD}}=6.0$ and $25^{\circ} \mathrm{C}(41)$.

${ }^{g} \mathrm{pD}=5.9$ and $37^{\circ} \mathrm{C}$ (42 and references therein). Lys-Pro117 is $91 \%$ cis and HisPro47 is $9 \%$ cis in the folded unligated protein. Lys-Pro117 is greater than $98 \%$ cis in the folded ligated protein.

${ }^{h} \mathrm{pD}=5.6$ and $25^{\circ} \mathrm{C}(43)$.

of the nonproline bonds and 5.2\% of the proline bonds are in a cis conformation in folded proteins (32). Conversely, an unfolded protein at equilibrium has nonproline bonds exclusively in the trans conformation and 6-38\% of the proline bonds in the cis conformation, depending on the identity of the residue preceding proline. The latter values are based on data by Reimer et al. (33) on capped pentapeptides with 20 different amino acids at the Xaa-Pro position (see Table 3).

Transiently unfolded states under native conditions in the hydrogenexchange experiments have the proline bonds in the same conformation as in the folded protein because the rate of refolding and hydrogen exchange is often much faster than the rate of proline 


\section{Table 3}

Proline Isomerization Based on Ac-Ala-Xaa-Pro-Ala-Lys- $\mathrm{NH}_{\mathbf{2}}{ }^{\mathrm{a}}$

\begin{tabular}{lcccc}
\hline Xaa & $\%$ cis $^{b}$ & $\mathrm{~K}_{\text {Pro }} \mathrm{U}_{c}$ & $\mathrm{RT} \ln \left(1+\mathrm{K}_{\text {Pro }} \mathrm{U}^{d}\right.$ & $\mathrm{RT} \ln \left(1+1 / \mathrm{K}_{\text {Pro }} \mathrm{U}^{e}\right.$ \\
\hline Pro & 6.0 & 15.67 & 1.67 & 0.037 \\
Lys & 6.8 & 13.71 & 1.59 & 0.042 \\
Arg & 7.2 & 12.89 & 1.56 & 0.044 \\
Asp & 7.3 & 12.70 & 1.55 & 0.045 \\
Ala & 7.7 & 12.00 & 1.52 & 0.047 \\
Cys & 8.7 & 10.49 & 1.45 & 0.054 \\
Glu & 9.0 & 10.11 & 1.43 & 0.056 \\
Thr & 9.4 & 9.64 & 1.40 & 0.058 \\
His(0) & 9.5 & 9.53 & 1.39 & 0.059 \\
Met & 10.0 & 9.00 & 1.36 & 0.062 \\
Ser & 10.3 & 8.71 & 1.35 & 0.064 \\
Val & 10.4 & 8.62 & 1.34 & 0.065 \\
Gln & 11.5 & 7.70 & 1.28 & 0.072 \\
Asn & 11.6 & 7.62 & 1.28 & 0.073 \\
Leu & 12.0 & 7.33 & 1.26 & 0.076 \\
Ile & 12.0 & 7.33 & 1.26 & 0.076 \\
Gly & 13.7 & 6.30 & 1.18 & 0.087 \\
His(+) $)^{g}$ & 16.5 & 5.06 & 1.07 & 0.107 \\
Phe & 23.0 & 3.35 & 0.87 & 0.155 \\
Tyr & 24.0 & 3.20 & 0.85 & 0.163 \\
Trp & 37.7 & 1.65 & 0.58 & 0.280 \\
\hline
\end{tabular}

${ }^{a}$ Replicated from Table 2 in Huyghues-Despointes et al. (12).

${ }^{b}$ The percentage of cis conformer measured at $23^{\circ} \mathrm{C}$ in $20 \mathrm{mM}$ sodium phosphate at $\mathrm{pH} 6.0$ (33). This value is relatively independent of temperature (38).

${ }^{c} \mathrm{~K}_{\mathrm{Pro}}$ is the equilibrium constant for cis $\Leftrightarrow$ trans isomerization of the indicated Xaa-Pro residue.

${ }^{d}$ Correction in $\mathrm{kcal} / \mathrm{mol}$ at $25^{\circ} \mathrm{C}$ (Eq. 10) for cis Xaa-Pro residues.

${ }^{e}$ Correction in $\mathrm{kcal} / \mathrm{mol}$ at $25^{\circ} \mathrm{C}$ (Eq. 11) for trans Xaa-Pro residues.

${ }^{f}$ Measured at $\mathrm{pH}$ 8.0.

${ }^{g}$ Measured at $\mathrm{pH} 3.5$.

isomerization (12). The protein typically spends less than $1 \mathrm{~s}$ in the transiently populated unfolded state before all the amide protons are exchanged. This is shown for the folding equilibrium of a protein with a proline residue in the sequence: 


$$
F_{c i s} \stackrel{K_{H X}}{\longrightarrow} U_{\text {cis }} \stackrel{K_{\text {pro }}^{U}}{\longrightarrow} U_{\text {trans }}
$$

where $\mathrm{F}_{\text {cis }}$ and $\mathrm{U}_{\text {cis }}$ are the native and unfolded states with a Pro residue exclusively in the cis conformation. $\mathrm{K}_{\text {pro }}^{\mathrm{U}}$ is the equilibrium constant for cis/trans proline isomerization in the unfolded state, and $\mathrm{K}_{\mathrm{HX}}$ is the equilibrium constant for folding exclusively in the cis conformation. The denatured states will have a higher free energy in the hydrogen-exchange experiments than under the traditional unfolding experiments where the proline bonds reach cis/trans equilibrium. $\Delta \mathrm{G}_{\mathrm{HX}}$ measures $\Delta \mathrm{G}$ for the first step in the equilibrium, but $\Delta \mathrm{G}_{\mathrm{U}}$ measures $\Delta \mathrm{G}$ for both steps $(\mathbf{1 5 , 3 4 )}$. The total difference is the stability from proline isomerization in the folded and unfolded states:

$$
\Delta \mathrm{G}_{\mathrm{pro}}=\Delta \mathrm{G}_{\mathrm{HX}}-\Delta \mathrm{G}_{\mathrm{U}}=\mathrm{RT} \ln \left(1+\mathrm{K}_{\mathrm{pro}}^{\mathrm{U}}\right) /\left(1+\mathrm{K}_{\mathrm{pro}}^{\mathrm{F}}\right)
$$

The full expression (Eq. 9) must be used for proteins such as Staphylococcal nuclease (SNase) where two proline residues flip between cis and trans conformers in the folded state (see Table 2).

For most proteins, where the proline conformation is fixed in the native conformation, the stability from proline isomerization caused by a cis proline in the native state can be reduced to:

$$
\Delta \mathrm{G}_{\mathrm{pro}}^{\mathrm{U}}=\mathrm{RT} \ln \left(1+\mathrm{K}_{\mathrm{pro}}^{\mathrm{U}}\right)
$$

or using Eq. 8, a trans proline in the native state can be:

$$
\Delta \mathrm{G}_{\mathrm{pro}}^{\mathrm{U}}=\mathrm{RT} \ln \left(1+1 / \mathrm{K}_{\mathrm{pro}}^{\mathrm{U}}\right)
$$

The $\Delta \mathrm{G}_{\text {pro }}^{\mathrm{U}}$ values for a cis proline in the native state are more than $1 \mathrm{kcal} / \mathrm{mol}$, while $\Delta \mathrm{G}_{\text {pro }}^{\mathrm{U}}$ for a trans proline are much smaller $(<0.3 \mathrm{kcal} / \mathrm{mol})$. Table 3 shows the $\Delta \mathrm{G}_{\text {pro }}^{\mathrm{U}}$ values for cis and trans proline conformers at $25^{\circ} \mathrm{C}$. The total effect of proline isomerization is determined by summing $\Delta \mathrm{G}_{\text {pro }}^{\mathrm{U}}$ contributions for all cis and trans proline residues in a protein. The conformation of a Xaa-Pro bond is detected by measuring the $\omega$ angle in the best NMR or $\mathrm{X}$-ray crystal structure of a protein. 
Until recently, it was commonly assumed that the proline bond was approx $20 \%$ cis in the unfolded state at equilibrium for all XaaPro residues in a protein. As a result, the stabilities of the most stable residues were not always considered to exchange by global unfolding (see refs. 35-37), because these stabilities did not agree and were often higher than the values from traditional methods.

\section{Conclusion}

If the corrections for the proline isomerization of the Xaa-Pro bond using values of Reimer et al. (33) are applied and if the traditional experiments are performed in $\mathrm{D}_{2} \mathrm{O}$, we find an excellent agreement between the corrected $\Delta \mathrm{G}_{\mathrm{HX}}$ and $\Delta \mathrm{G}_{\mathrm{U}}$ for most proteins (Table 1). This comparison leads to several important conclusions:

1. The most stable amide hydrogens generally exchange by global unfolding.

2. The unfolded states that exist under native conditions are thermodynamically equivalent to those that exist after solvent or thermal unfolding.

3. Chemical exchange rates from short peptides can model well $\mathrm{k}_{\mathrm{rc}}$, the exchange-rate constant of the open conformation.

4. The equilibrium constants for proline isomerization in capped pentapeptides can be used to correct for the higher free energy of the unfolded states in the hydrogen-exchange experiments.

\section{A Note on Nomenclature}

In the literature, the nomenclature for describing the hydrogenexchange process varies widely. Examples include defining the chemical exchange-rate constants as $\mathrm{k}_{\mathrm{rc}}, \mathrm{k}_{\mathrm{ch}}$, or $\mathrm{k}_{\mathrm{int}}$, the hydrogenexchange stabilities as $\Delta \mathrm{G}_{\mathrm{HX}}, \Delta \mathrm{G}_{\mathrm{HD}}$, or $\Delta \mathrm{G}_{\mathrm{ex}}$, the conformational stability as $\Delta \mathrm{G}_{\mathrm{U}}, \Delta \mathrm{G}_{\mathrm{W}}$, or $\Delta \mathrm{G}\left(\mathrm{H}_{2} \mathrm{O}\right)$, the hydrogen-exchange process as $\mathrm{HX}, \mathrm{HD}$, or hydrogen exchange, and the $\mathrm{pH}$ meter reading of the experiment in $\mathrm{D}_{2} \mathrm{O}$ as $\mathrm{pH}^{*}, \mathrm{pH}_{\text {read }}$, or $\mathrm{pD}$. In this chapter, all these terms are defined as the following: the random coil rate as $\mathrm{k}_{\mathrm{rc}}$, the hydrogen exchange stabilities as $\Delta \mathrm{G}_{\mathrm{HX}}$, the conformational sta- 
bility in $0 M$ denaturant as $\Delta \mathrm{G}_{\mathrm{U}}\left(\mathrm{D}_{2} \mathrm{O}\right)$ in deuterated solvent and $\Delta \mathrm{G}_{\mathrm{U}}\left(\mathrm{H}_{2} \mathrm{O}\right)$ in protonated solvent, the exchange process as hydrogen-exchange or $\mathrm{HX}$, and the $\mathrm{pH}$ meter reading as $\mathrm{pH}^{*}$. In the future, for the purpose of clarity, it would be advisable to universally adopt the same nomenclature, and we suggest that the nomenclature defined here would serve this purpose.

\section{Acknowledgment}

Work in the authors' laboratories is supported by the National Institutes of Health (J. M. Scholtz, C. N. Pace, and S. W. Englander) and the Robert E. Welch Foundation (J. M. Scholtz and C. N. Pace).

\section{References}

1. Pace, C. N., Shirley, B. A., McNutt, M., and Gajiwala, K. (1996) Forces contributing to the conformational stability of proteins. FASEB J. 76, 75-83.

2. Pace, C. N. (1975) The stability of globular proteins. CRC Crit. Rev. Biochem. 3, 1-43.

3. Freire, E. (1995) Thermal denaturation methods in the study of protein folding. Methods Enzymol. 259, 144-168.

4. Pace, C. N. and Scholtz, J. M. (1997) Measuring the conformational stability of a protein, in Protein Structure. A Practical Approach, (Creighton, T. E., ed.), Oxford University Press Inc., New York, NY, pp. 299-321.

5. Jaenicke, R. (1987) Folding and association of proteins. Prog. Biophys. Mol. Biol. 49, 117-237.

6. Makhatadze, G. I. (1999) Thermodynamics of protein interactions with urea and guanidinium hydrochloride. J. Phys. Chem. 103, 4781-4785.

7. Chamberlain, A. K. and Marqusee, S. (1997) Touring the landscapes: partially folded proteins examined by hydrogen exchange. Structure 5, 859-863.

8. Hvidt, A. and Neilson, S. O. (1966) Hydrogen exchange in proteins. Adv. Protein Chem. 21, 287-386.

9. Bai, Y., Milne, J. S., Mayre, L., and Englander, S. W. (1993) Primary structure effects on peptide group hydrogen exchange. Proteins 17, 75-86. 
10. Loh, S. N., Rohl, C. A., Kiefhaber, T., and Baldwin, R. L. (1996) A general two-process model describes the hydrogen exchange behavior of RNase A in unfolding conditions. Proc. Natl. Acad. Sci. USA 93, 1982-1987.

11. Qian, H. and Chan, S. I. (1999) Hydrogen exchange kinetics of proteins in denaturants: a generalized two-process model. J. Mol. Biol. 286, 607-616.

12. Huyghes-Despointe, B. M. P., Scholtz, J. M., and Pace, C. N. (1999) Protein conformational stabilities can be determined from hydrogenexchange rates. Nat. Struct. Biol. 6, 910-912.

13. Connelly, G. P., Bai, Y., Jeng, M.-F.. amd Englander, S. W. (1993) Isotope effect in peptide group hydrogen exchange. Proteins 17, 87-92.

14. Molday, R. S., Englander, S. W., and Kallen, R. G. (1972) Primary structure effects on peptide group hydrogen exchange. Biochemistry 11, 150-158.

15. Bai, Y., Milne, J. S. Mayne, L., and Englander, S. W. (1994) Protein stability parameters measured by hydrogen exchange. Proteins 20, 4-14.

16. Roder, H., Wagner, G., and Wüthrich, K. (1985) Amide proton exchange in proteins by EX1 kinetics: studies of the basic pancreatic trypsin inhibitor at variable $\mathrm{pD}$ and temperature. Biochemistry 24, 7396-7407.

17. Tüchsen, E. and Woodward, C. (1987) Biochemistry 26, 8073-8078.

18. Swint-Kruse, L. and Robertson, A. D. (1996) Temperature and pH dependences of hydrogen exchange and global stability for ovomucoid third domain. Biochemistry 35, 171-180.

19. Mayo, S. L. and Baldwin, R. L. (1993) Guanidinium chloride induction of partial unfolding in amide proton exchange in RNase A. Science 262, 873-876.

20. Bai, Y., Sosnick, T. R., Mayne, L., and Englander, S. W. (1995) Protein folding intermediates: native state hydrogen exchange. Science 269, 192-197.

21. Chamberlain, A. K., Handel, T. M., and Marqusee, S. (1996) Detection of rare partially folded molecules in equilibrium with the native conformation of RNase H. Nat. Struct. Biol. 3, 782-787.

22. Grantcharova, V. P. and Baker, D. (1997) Folding dynamics of the src SH3 domain. Biochemistry 36, 15,685-15,692.

23. Yi, Q., Scalley, M. L., Simons, K. T., Gladwin, S. T., and Baker, D. (1997) Characterization of the free energy spectrum of peptostreptococcal protein L. Fold. Des. 2, 271-279. 
24. Bhuyan, A. K. and Udgaonkar, J. B. (1998) Two structural subdomains of barstar detected by rapid mixing NMR measurement of amide hydrogen exchange. Proteins 30, 295-308.

25. Fuentes, E. J. and Wand, A. J. (1998) Dynamics and stability of apocytochrome b562 examined by hydrogen exchange. Biochemistry 37, 3687-3698.

26. Fuentes, E. J. and Wand, A. J. (1998) Local stability and dynamics of apocytochrome B562 examined by the dependence of hydrogen exchange on hydrostatic Pressure. Biochemistry 37, 9877-9883.

27. Huyghes-Despointe, B. M. P., Langhoest, U., Steyaert, J., Pace, C. N., and Scholtz, J. M. (1999) Hydrogen-exchange stabilities of RNase T1 and variants with buried and solvent-exposed Ala $\rightarrow$ Gly mutations in the helix. Biochemistry

28. Pace, C. N., Laurents, D. V., and Thomson, J. A. (1990) pH dependence of the urea and guanidine hydrochloride denaturation of ribonuclease A and ribonuclease T1. Biochemistry 29, 2564-2572.

29. Glasoe, P. F. and Long, F. A. (1960) Use of glass electrodes to measure acidities in deuterium oxide. J. Phys. Chem. 64, 188-193.

30. Oas, T. G. and Toone, E. J. (1997) Thermodynamic solvent isotope effects and molecular hydrophobicity, in Adv. Biophys. Chem. (Bush, C., ed.), JAI Press, Inc., Greenwich, CT pp. 1-52.

31. Makhatadze, G. I., Clore, G. M., and Gronenborn, A. M. (1995) Solvent isotope effect of protein stability. Nat. Struct. Biol. 2, 852-855.

32. Jabs, A., Weiss, M. S., and Hilgenfeld, R. (1999) Non-proline cis peptide bonds in proteins. J. Mol. Biol. 286, 291-304.

33. Reimer, U., Scherer, G., Drewello, M., Kruber, S., Schutkowski, M., and Fischer, G. (1998) Side-chain effects of peptidyl-prolyl cis/trans isomerization. J. Mol. Biol. 279, 449-460.

34. Sharp, K. A. and Englander, S. W. (1994) How much is a stabilizing bond worth? Trends Biochem. Sci. 19, 526-529.

35. Kragelund, B. B., Knudsen, J., and Poulsen, F. M. (1995) Local perturbations by ligand binding of hydrogen deuterium exchange kinetics in a four-helix bundle protein, acyl coenzyme A binding protein (ACBP). J. Mol. Biol. 250, 695-706.

36. Li, R. and Woodward, C. (1999) Hydrogen exchange and protein folding. Protein Sci. 8, 1571-1591.

37. Neira, J. L., Sevilla, P., Menéndez, M., Bruix, M., and Rico, M. (1999) Hydrogen exchange in ribonuclease A and ribonuclease S: 
evidence for residual structure in the unfolded state under native conditions. J. Mol. Biol. 285, 627-643.

38. Sivaraman, T., Kumar, T. K. S., and Yu, C. (1999) Investigation of the structural stability of cardiotoxin analogue III from the taiwan cobra by hydrogen-deuterium exchange kinetics. Biochemistry 38, 9899-9905.

39. Chakshusmathi, G., Ratnaparkhi, G. S., Madhu, P. K., and Varadarajan, R. (1999) Native-state hydrogen-exchange studies of a fragment complex can provide structural information about the isolated fragments. Proc. Natl. Acad. Sci. USA 96, 7899-7904.

40. Llinás, M., et al. (1999) The energetics of T4 lysozyme reveal a hierarchy of conformations. Nat. Struct. Biol. 6, 1072-1076.

41. Loh, S. N., Prehoda, K. E., Wang, J., and Markley, J. L. (1993) Hydrogen exchange in unligated and ligated staphylococcal nuclease. Biochemistry 32, 11,022-11,028.

42. Wrabl, J. and Shortle, D. (1999) A model of the changes in denatured state structure underlying $\mathrm{m}$ value effects in staphylococcal nuclease. Nat. Struct. Biol. 6, 876-883.

43. Brandts, J. F., Halvorson, H. R., and Brennan, M. (1975) Consideration of the possibility that the slow step in protein denaturation reactions is due to cis-trans isomerization of proline residues. Biochemistry 14, 4953-4963. 